\title{
Phosphorus fixing capacity of the Oxic Rhodustalf- alfisol soil in the Chotanagpur plateau region of Eastern India
}

\author{
Prabir Ghosal $^{1^{\star}}$, Trishit Chakraborty ${ }^{2}$, Pabitra Banik $^{3}$ \\ ${ }^{1}$ Agricultural and Ecological Research Unit, Indian Statistical Institute, Kolkata, India; *Corresponding Author: pkghosal@isical.ac.in \\ ${ }^{2}$ Department of ASEPAN, Palli Siksha Bhavana, Sriniketan, Visva Bharati, Bolpur, India; \\ ${ }^{3}$ Agricultural and Ecological Research Unit, Indian Statistical Institute, Kolkata, India.
}

Received 4 September 2011; revised 12 October 2011; accepted 30 October 2011.

\begin{abstract}
The P-fixing capacity of a soil governs the P-nutrition of crop plants. P-nutrition of the crop plant is more a soil problem and a higher dose of phosphatic fertilizer is necessary for soils having high $P$-fixing capacity. The phenomenon of P-fixation and the great variation in the $P$ fixing capacity of different soils has thus important bearing on crop response to P-application. The eastern plateau region of India with acid lateritic soil is chronically deficient in available phosphorus resulting in very low productivity. An experiment was thus carried out to estimate the P-fixing capacity of soil collected from two depths, $0-20 \mathrm{~cm}$ and $20-50 \mathrm{~cm}$, from the Agricultural experimental farm of Indian Statistical Institute, situated at Giridih, Jharkhand, in the eastern India. The soil was acidic in reaction ( $\mathrm{pH}-5.4)$ with presence of $\mathrm{Fe}(1.60 \%)$ and Al (17.2\%). The P-fixing capacity of the soil was estimated to be $59.60 \%$ and $64.94 \%$ for the surface and the subsurface soil respectively showing lower P-fixing capacity of the surface soil as compared to the subsurface soil which may be due to presence of more organic matter in the surface soil as organic molecules released on decomposition of organic matter complexes with Fe and Al in the soil thereby blocking the P-fixing sites in the soil.
\end{abstract}

Keywords: P-Fixing Capacity; P-Nutrition; P-Fixation

\section{INTRODUCTION}

Phosphorus (P) is an essential element for plant growth and productivity, and lack of available $\mathrm{P}$ in soils can se- verely affect crop yields [1]. Plants extract $\mathrm{P}$ from the soil solution in the form of orthophosphate ion $\left(\mathrm{H}_{2} \mathrm{PO}_{4}^{-}\right.$ or $\mathrm{HPO}_{4}^{-}$) and there is strong competition between plants and soil minerals for these forms of P, particularly in the highly weathered soils of the tropics, most of which contain large amounts of iron oxides, aluminum oxides, or amorphous alumino-silicate clays. These soil minerals "fix" $\mathrm{P}$ firmly through a process known as sorption, making the $\mathrm{P}$ virtually unavailable for plant uptake [2].

The P-fixing capacity of a soil is influenced by a number of factors, such as $\mathrm{pH}, \mathrm{CaCO}_{3}$, sesquioxides, moisture and clay contents [3]. When phosphatic fertilizers are added to a soil, a series of chemical reactions take place between the soil constituents and soluble phosphorus, rendering the added phosphorus relatively less available. The soil factors contributed to 80 to 83 per cent of the variations in the amounts of $\mathrm{P}$ fixed at various levels of added $\mathrm{P}$ and also of the maximum $\mathrm{P}$ fixation capacity [4]. Thus, it is now well understood that P-nutrition of the crop plants is more a soil problem and a higher dose of phosphatic fertilizers are thus necessary for soils having high P-fixing capacity. It has been reported that about $10 \%$ to $30 \%$ of added phosphorus, is utilized by the crop and the rest is accumulated in the soil in one form or another thereby enriching the reserve phosphorus pool of the soil. An increase in the Relative Agronomic Efficiency of less water-soluble P sources on high soil $\mathrm{P}$ adsorption capacity has also been reported [5]. Thus, the phenomenon of P-fixation and the great variation in P-fixing capacity of different soils has important bearing on crop response to phosphorus application.

The eastern plateau region of India is chronically low in productivity of food grains [6]. One of the reasons for this is attributed to very low phosphate availability of the soil (20 - $25 \mathrm{~kg} \mathrm{P}_{2} \mathrm{O}_{5} / \mathrm{ha}$ ) due to its acidic reaction and presence of large amount of hydroxides of iron and alu- 
minum [7].

With this background, an experiment was carried out in the laboratory of the Agricultural and Ecological Research Unit of Indian Statistical Institute at Kolkata, on soils collected from the Agricultural farm of Indian Statistical Institute situated at Giridih, Jharkhand in the Chotanagpur plateau region of eastern India.

\section{MATERIALS AND METHODS}

The composite soil samples were collected from Agricultural experimental farm of Indian Statistical Institute situated at Giridih, Jharkhand, from two depths, 0 - 20 $\mathrm{cm}$ and $20-50 \mathrm{~cm}$. The soil samples were air dried, ground and passed through $2 \mathrm{~mm}$ sieve. The physicochemical properties of the experimental soil are presented in Tables 1(a) and (b).

Treatment Details :

\begin{tabular}{cccc}
\hline $\begin{array}{c}\text { Concentrations of } \mathrm{P} \\
\text { added as } \mathrm{KH}_{2} \mathrm{PO}_{4} \\
(\mu \mathrm{g} / \mathrm{cc})\end{array}$ & $\begin{array}{c}\text { Soil } \\
\text { Taken } \\
(\mathrm{g})\end{array}$ & $\begin{array}{c}\text { Effective concentration } \\
\text { on addition of } 1 \mathrm{cc} \mathrm{P} \\
\text { solution in 2.5 g of soil } \\
(\mu \mathrm{g} / \mathrm{g})\end{array}$ & $\begin{array}{c}\text { Soil sampling } \\
\text { depth }(\mathrm{cm})\end{array}$ \\
\hline 0 & 2.5 & 0 & $0-20$ \\
50 & 2.5 & 20 & $20-50$ \\
100 & 2.5 & 40 & \\
150 & 2.5 & 60 & \\
200 & 2.5 & 80 & \\
300 & 2.5 & 120 & \\
400 & 2.5 & 160 & \\
500 & 2.5 & 200 & \\
600 & 2.5 & 240 & \\
750 & 2.5 & 300 & \\
\hline
\end{tabular}

\section{METHODOLOGY}

Two and a half gram (2.5 g) of air dried sieved soil was taken for each treatment, for two soil depths (0 - 20 $\mathrm{cm}$ and 20 - $50 \mathrm{~cm}$ depth), in 100 cc conical flask. One milliliter $(1 \mathrm{ml})$ of different concentrations $(0 \mu \mathrm{g} / \mathrm{cc}, 50$ $\mu \mathrm{g} / \mathrm{cc}, 100 \mu \mathrm{g} / \mathrm{cc}, 150 \mu \mathrm{g} / \mathrm{cc}, 200 \mu \mathrm{g} / \mathrm{cc}, 300 \mu \mathrm{g} / \mathrm{cc}, 400$ $\mu \mathrm{g} / \mathrm{cc}, 500 \mu \mathrm{g} / \mathrm{cc}, 600 \mu \mathrm{g} / \mathrm{cc}$ and $750 \mu \mathrm{g} / \mathrm{cc})$ of soluble phosphorus, in the form of potassium dihydrogen phosphate was carefully added to each flask as per treatment so as to wet the soil uniformly. The conical flasks were then plugged and incubated at room temperature $\left(30^{\circ} \mathrm{C}\right)$ for 96 hours and available phosphate (P) was then estimated by Olsen's method [8]. The whole experiment was carried out in three sets and the mean data have been presented. According to Nad et al. (1975) the Pfixation capacity of soil was worked out using the equation

$$
b=\frac{\sum x y-N \bar{x} \bar{y}}{\sum x^{2}-N(\bar{x})^{2}}
$$

where, $b$ represents the fraction of added $P$, which remained available under the condition of the experiment. Added $\mathrm{P}$, released $\mathrm{P}$ and number of concentrations of $\mathrm{P}$ added (10) are represented by $x, y$ and $N$ respectively. The method is based on the relationship between available $\mathrm{P}$ (i.e. estimated $\mathrm{P}$ ) and added $\mathrm{P}$, which is virtually linear and therefore the slope of the curve relating released $\mathrm{P}$ (y-axis) and added P ( $x$-axis) was calculated out by the standard equation mentioned above. The percent of $\mathrm{P}$-fixation of added $\mathrm{P}$ is thus given by

Phosphate fixation capacity $(\%), \mathrm{P}=100-b \times 100$

Table 1. (a) Physico chemical characteristics of the experimental soil; (b) Mechanical composition of the soil (in \%).

(a)

\begin{tabular}{|c|c|}
\hline Parameters & Values \\
\hline \multicolumn{2}{|l|}{ Physical characteristics: } \\
\hline Particle density (g/cc) & 2.49 \\
\hline Bulk density (g/cc) & 1.33 \\
\hline Water holding capacity (\%) & 23.1 \\
\hline \multicolumn{2}{|l|}{ Chemical characteristics: } \\
\hline $\mathrm{pH}$ & 5.4 \\
\hline Organic Carbon (\%) & 0.52 \\
\hline Total Nitrogen (\%) & 0.059 \\
\hline Available Nitrogen (kg/ha) & 135.0 \\
\hline Available P (kg/ha) & 5.6 \\
\hline Available K (kg/ha) & 89.5 \\
\hline Cation Exchange Capacity (me/100g) & 10.19 \\
\hline Aluminium Oxide (\%) & 17.2 \\
\hline Iron Oxide (\%) & 1.60 \\
\hline
\end{tabular}

(b)

\begin{tabular}{|c|c|c|c|c|}
\hline \multicolumn{2}{|c|}{ Sand } & \multirow{2}{*}{ Silt } & \multirow{2}{*}{ Clay } & \multirow{2}{*}{ Textural class } \\
\hline Fine & Coarse & & & \\
\hline 27.4 & 33.8 & 11.9 & 26.9 & Sandy Clay Loam \\
\hline
\end{tabular}




\section{RESULTS AND DISCUSSION}

The P-fixing capacity of a soil can be drawn from the relationship of added phosphorus and extracted available phosphorus on addition of graded quantum of phosphorus, after a time interval, in a particular soil. The data on addition of graded amount of inorganic phosphorus (Table 2) at both the soil depth indicated that the relationship between available and added phosphorus was virtually linear (Figure 1). This was in accordance with the findings of Nad et al. (1975). Thus the slope " $b$ ", which is the fraction of the added phosphorus remaining available under the conditions of the experiment, was calculated using the formula mentioned above and the values were 0.404 and 0.351 for soils from $0-20 \mathrm{~cm}$ and 20 $50 \mathrm{~cm}$ depths respectively. The percent fixation of phosphorus in the soil came out to $59.60 \%$ and $64.94 \%$ for the surface and subsurface soil respectively. The P-fixing values were close to that of the lateritic soil at Mangalore having $\mathrm{pH}$ 5.6. It may be noted that the subsurface soil has higher P-fixing capacity than the surface soil. This may be attributed to lower phosphorus content in the subsurface as well as presence of more organic matter in the surface as compared to subsurface soil. Organic matter on decomposition releases organic molecules, which form complexes with $\mathrm{Fe}$ and $\mathrm{Al}$ ions thereby blocking the sites which are mainly responsible for fixation of phosphorus [9-11]. This is supported by results of another experiment [12] conducted in the same site which showed that addition of organic manure markedly increased the availability of phosphorus in the soil. This increase in phosphorus availability in the soil was found to be statistically significant over control treatment and also over treatments with inorganic fertilizers.

Table 2. Available $P(\mu \mathrm{g} / \mathrm{g})$, on addition of graded amount of inorganic phosphorus to the soil.

\begin{tabular}{ccc}
\hline \multirow{2}{*}{ Added P $(\mu \mathrm{g} / \mathrm{g})$} & \multicolumn{2}{c}{ Available P $(\mu \mathrm{g} / \mathrm{g})$} \\
\cline { 2 - 3 } & $0-20 \mathrm{~cm}$ & $20-50 \mathrm{~cm}$ \\
\hline 0 & 7.96 & 5.96 \\
40 & 16.92 & 12.96 \\
60 & 21.56 & 18.92 \\
80 & 30.88 & 25.24 \\
120 & 44.48 & 39.56 \\
160 & 56.44 & 53.12 \\
200 & 83.96 & 77.80 \\
240 & 97.60 & 88.96 \\
300 & 119.52 & 103.60 \\
\hline
\end{tabular}

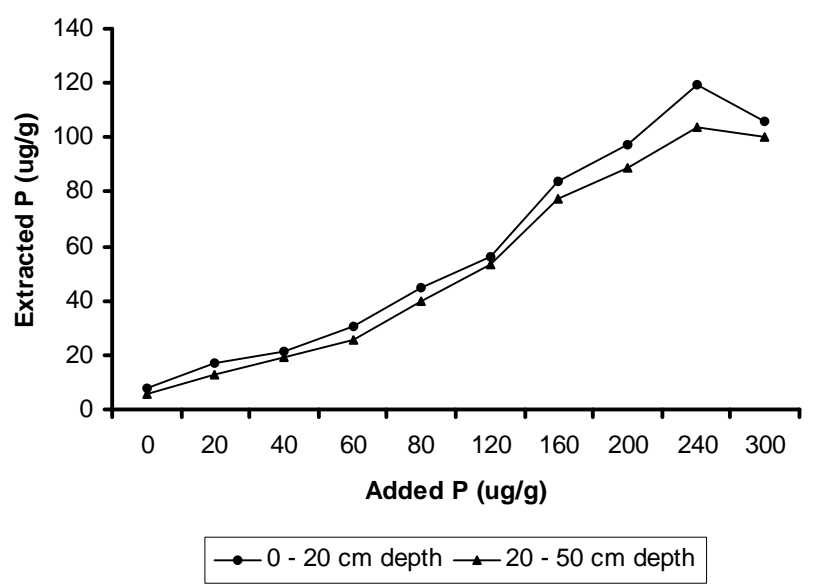

Figure 1. Available $\mathrm{P}$ on addition of graded amount of inorganic phosphorus in the soil collected from two depths.

Thus the soil of the eastern plateau area is characterized with low soil available phosphorus and as much as $60 \%$ of the applied P can get fixed in the soil. Under such circumstance the P fixation capacity must be overcome by application of fertilizer $\mathrm{P}$ at a higher rate or by applying slow releasing $\mathrm{P}$ fertilizers as phosphate rocks to have enough P left over for crops to increase productivity.

\section{REFERENCES}

[1] Toor, G.S. (2009) Enhancing phosphorus availability in low phosphorus soils by using poultry manure and commercial fertilizers. Soil Science, 174, 358-364. doi:10.1097/SS.0b013e3181a7e716

[2] Hue, N.V. and Silva, J.A. (2000) Organic soil amendments for sustainable agriculture: Organic sources of nitrogen, phosphorus and potassium. Plant nutrient management in Hawai's Soils, approaches for tropical and subtropical agriculture. In: Silva, J.S. and Uchida, R., College of Tropical Agriculture and Human Resources, University of Hawaii, Manoa.

[3] Nad, B.K., Goswami, N.N. and Leelavathi, C.R. (1975) Some factors influencing the phosphorus fixing capacity of Indian soils. Journal of Indian Society of Soil Science, 23, 319-327.

[4] Das, P.K., Sahu, G.C., Nanda, S.S.K. and Acharya, N. (1993) Effect of soil characterestics on phosphate fixing capacity of some alfisols. Journal of the Indian Society of Soil Science, 41, 51-55.

[5] Prochnow, L.I., Quispe, J.F.S., Francisco, E.A.B. and Braga, G. (2006) Effectiveness of phosphate fertilizers of different water solubilities in relation to soil phosphorus adsorption. Scientia Agricola, 63, 333-340. doi:10.1590/S0103-90162006000400004

[6] Mahapatra, I.C., Sahay, S.N. and Mathur, B.S. (1984) Agriculture in the 1980s in the plateau and sub plateau region in Bihar. Indian Agriculturist, 28, 79-90.

[7] Tisdale, S.L., Nelson, W.L. and Beaton, J.D. (1993) Soil fertility and fertilizers. Macmillan Publishing Co. Inc., New York. 
[8] Jackson, M.L. (1972) Soil chemical analysis. Prentice Hall of India Pvt. Ltd., New Delhi.

[9] Juo, A.S.R. and Fox, R.L. (1977) Phosphate sorption characteristics of some Bench Mark soils of West Africa. Soil Science, 124, 370-376. doi:10.1097/00010694-197712000-00010

[10] Subramanian, K.S. and Kumaraswamy, K. (1989) Effect of continuous cropping and fertilization on the phosphate fixation capacity of soil. Journal of Indian Society of Soil Science, 37, 682-686.

[11] Brouwere, K.D., Thijs, A., Hens, M. and Merckx, R.
(2003) Forms and availability of soilphosphorus in temperate forests in southern chile and flanders. Gayana Botánica, 60, 17-23.

[12] Banik, P., Ghosal, P.K., Sasmal, T.K., Bhattacharya, S., Sarkar, B.K. and Bagchi, D.K. (2006) Effect of organic and inorganic nutrients for soil quality conservation and yield of rainfed low land rice in sub tropical plateau region. Journal of Agronomy and Crop Science, 192, 331343. doi:10.1111/j.1439-037X.2006.00219.x 